\title{
Weblog-Based Learning and Classroom-Based Learning with High, Adequate, and Low Motivation Indonesian Primary EFL Learners
}

\author{
Irma Savitri Sadikin* \\ Department of English Language Education, Faculty of Teacher Training and Education University \\ Esa Unggul University \\ Jakarta, Indonesia \\ *irma.savitri@esaunggul.ac.id
}

\begin{abstract}
As teaching English in Elementary school enters the mainstream classroom, young learners face numerous challenges. The terms of weblog-based learning technique (WBL) and classroom-based learning technique (CBL) are each used to help young learners in learning integrated English. Particularly, this current study aimed to 1) find out the effect of students with high, adequate, and low motivation towards their English achievements through Weblog-based learning (WBL) and Classroom-Based Learning (CBL); 2) to examine WBL compared to $\mathrm{CBL}$ as teaching techniques in improving English language skills of students with different level of motivations; and 3) to show the interaction among teaching techniques and motivations to students' mastery of English language skill. Mixed method research with sequential explanatory was employed. 2 × 3 factorial design of experimental research was carried out, involving two groups and employing pre-test, treatments, and post-test. Data from English cognitive test were analysed using two-way ANOVA. Sixty participants were assigned at the fifth grade at one of private Islamic schools in Indonesia. The result shows that the level of significance by using WBL and CBL were smaller than $0.05(5 \%)$ which showed the improvement on both techniques. However, the result of the study proved that WBL is more effective to improve the learners' English language skills than CBL. Both of techniques and the students' motivations to English language skills do not show any interactions. It indicates that either the implementation of WBL or CBL could help students in mastering English to overall motivations.
\end{abstract}

Keywords-Weblog-Based Learning, Classroom-Based Learning, motivation, young learners

\section{INTRODUCTION}

Online learning offers huge opportunities for learning and access to a vast amount of knowledge and information. In relation with it, young learners, nowadays, prefer acquiring from seeing and reading could advantage which could study well illustrated by pictures or videos so online learning environment provides a wide choice and the teacher can explore with it [1, p. 30]. The significant works of literature indicated that online learning for young learners supported critical thinking, problem-solving, communication and interaction, and flexibility in time management [2,3]. Besides, some previous research reveals that the use of computer supports and increases young children's skill in the social, cognitive, language literacy and writing. Therefore, adult guidance for children using a computer is associated with increases in abstract reasoning, planning behaviour, visualmotor coordination, and visual memory [4,5]. Weblog is an online learning which can be defined as personalized learning. In relation to this, weblog's characteristics are common across personalize learning classroom. It actually does not require high IT skills [6,7] which available on the internet and it is good repositories for storing data generated in the classroom.

Moreover, Classroom-based learning atmosphere significantly influence the English language learning because of the physical and social environment of the of the classroom [8-10]. Mastering a different language is not an easy task for students or EFL teachers. Teachers play a significant role in the classroom. Most of what happens in the classroom affects their preferences, types, strategies and directions. Students' level attitude toward learning English has been influenced the students' learning. Some of the studies revealed that positive attitudes encourage the learners to have a high positive orientation in learning English [11-14]. The studies show that having a high motivation and a positive attitude toward $\mathrm{L} 2$ can help the learners to acquire the language and communicate effectively using the English language. Therefore, designing and implementation of various techniques in language learning can change student's attitude positively toward L2 learning. In relation to this, positive prior attitude toward L2 is also a crucial factor to be successful in language learning $[15,16]$.

The studies based on Weblog-based learning and Classroom-based learning have been mostly carried out in higher EFL classes and emphasizes on writing and reading skill. However, this current study deals with young learners for TEFL to report the interaction among teaching techniques (WBL and CBL) and their mastery of English to students with high, adequate, and low motivation. 


\section{METHODS}

The present study aims to examine the effect of WBL and CBL in teaching English as a foreign language to students with high motivation, adequate motivation, low motivation, and the overall motivation (high, adequate, and low motivation students) in young learners' context between those taught using WBL technique and CBL technique, to find out which one is more effective, to find out which one is more effective between WBL and CBL for high, adequate, and low motivation students, and to find out whether there is interaction among the techniques, motivation, and students' English integrated skills of primary school learners. The experimental research was conducted in this study because the researcher wanted to test the hypothesis to create cause- and-effect relationships. As Fraenkel and Wallen [17, p. 231] state experimental research is a type of research in which at least one independent variable is manipulated, other relevant variables are controlled, and the effect on one or more dependent variables is observed. Dealing with the design, a $3 \times 2$ factorial design ANOVA was applied in this study since there are two independent variables (weblogbased learning technique and classroom-based learning technique and motivation).

The population of this study was $5^{\text {th }}$ graders of private Islamic school in West Java, Indonesia. There are two groups, experimental and control groups to determine the effects of intensity (low, adequate, high) motivation in learning English. The experimental group received WBL treatment and the control group continued to be taught by CBL as their teacher's usual technique. Moreover, the experimental and control groups as dependent variables were given English pre-test in the first meeting. The number of samples was sixty students, thirty students for each class.

A set of motivational questionnaire was used in this study. The questionnaire was adapted from Motivational Strategies for Learning Questionnaire (MSLQ) $[18,19]$. It was adapted to the condition and characteristic of Indonesian primary school classroom. The students were generally divided based on their performance on the test into upper, adequate, and lower groups, so that the proportions happens to be 27\%upper group, $46 \%$ adequate group, and $27 \%$ lower group respectively [20, p. $105]$.

\section{FINDINGS AND DISCUSSION}

The pre-test was given to the experimental and control learners after its validity and reliability have been measured. Meanwhile, post-test was held to figure out whether or not students' English language skills have improved. The significant result that can be found from post- test scores. There were some improvement scores to students' language skill. The post-test shows the improvement of the score after giving the treatments for both groups. Therefore, it can be inferred that both techniques have given the contribution to students with high, adequate, and low motivation. However, the improvement scores on overall motivation in WBL class are better than the scores in CBL class.

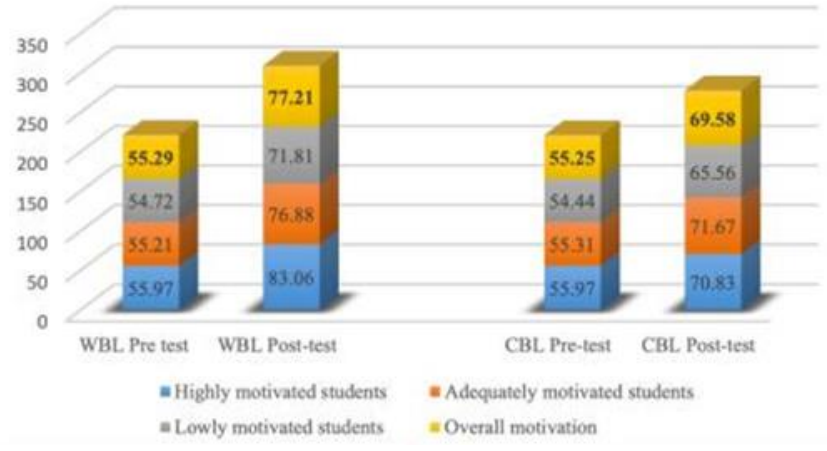

Fig. 1. The mean of pre-test and post-test on English language skills in WBL and CBL class.

Then, the normality was conducted to know whether the data is distributed normally or not. One-Sample KolmogorovSmirnov Test showed that the significant values of the pre-test score was higher than $0.05(0.512>0.05)$. It means that the data in the pre-test were distributed normally. Therefore, the result of the normality test of post-test showed that the significant value of the post-test score was higher than $0.05(0.746>0.05)$. It can be inferred that data of both experimental groups have a normal distribution. The result of the homogeneity test of pretest for students with high, adequate, and low motivations showed that the significant value is $>0.05$ or $(0.283>0.05)$. It can be concluded that the data distribution was homogeny.

Figure 1 describes the effectiveness of weblog-based learning and classroom-based learning to highly, adequately, lowly, and overall motivated students. It can be found that the comparison between experimental group and control group which the $\mathrm{N}$ was 60 . The mean of the experimental group was 77.21 and the mean of the control group was 69.58. Despite the improvement in the scores of both techniques, the class which was treated with WBL technique was better than the class which was taught with CBL technique.

\section{A. Teaching English Using Weblog-Based Learning Technique to Highly, Adequately, and Lowly Motivated Students}

After the treatment of WBL technique to the learners with high motivation, the mean of their cognitive skill is 83.06 . This shows that the mean score of the post-test result was better than the mean score of pre-test result. The improvement of students' cognitive skill after the implementation of WBL to students with high motivation, in general, is scored 0.62 and the standard deviation (SD) is 0.05 , and according to Hake's Criteria [21], the improvement is categorized as adequate. It can be found that weblogging facilitated the students to write many things such as uploading assignments, posting writing, and commenting on other students' posts. All their works in writing were posting in the classroom blog in order to let the students get paperless access and by collecting as their eportfolio. As a matter of fact, this technique led the student to get used to writing leisurely, informally, and comfortably. Moreover, based on the observation data, many highly 
motivated students showed their eagerness in writing because weblog is practical and user- friendly.

TABLE I. DESCRIPTION OF STUDENTS LANGUAGE SKILLS IN THE USE OF WBL to STUDENTS WITH HIGH, ADEQUATE, AND LOW MOTIVATION

\begin{tabular}{|c|c|c|c|c|c|}
\hline \multicolumn{6}{|c|}{ Teaching English Using Weblog-Based Learning } \\
\hline \multicolumn{2}{|c|}{ Description } & $\begin{array}{c}\text { High } \\
\text { Motivation }\end{array}$ & $\begin{array}{c}\text { Adequate } \\
\text { Motivation }\end{array}$ & $\begin{array}{c}\text { Low } \\
\text { Motivation }\end{array}$ & $\begin{array}{c}\text { Overall } \\
\text { Motivation }\end{array}$ \\
\hline \multirow[t]{4}{*}{ Pre-test } & Mean & 55.97 & 55.21 & 54.72 & 55.29 \\
\hline & $S D$ & 7.31 & 6.23 & 7.92 & 6.86 \\
\hline & $\begin{array}{l}\text { Min } \\
\text { score }\end{array}$ & 43.75 & 41.25 & 41.25 & 41.25 \\
\hline & $\begin{array}{l}\text { Max } \\
\text { score }\end{array}$ & 63.75 & 63.75 & 66.26 & 66.25 \\
\hline \multirow[t]{2}{*}{ Normality } & $\begin{array}{l}\text { Sig (2- } \\
\text { tailed) }\end{array}$ & 0.554 & 0.489 & 0.995 & 0.512 \\
\hline & $\mathrm{H}_{o}$ & Accepted & Accepted & Accepted & Accepted \\
\hline \multirow[t]{5}{*}{ Post-test } & Mean & 83.06 & 76.88 & 71.81 & 77.21 \\
\hline & $S D$ & 3.81 & 2.58 & 4.85 & 5.72 \\
\hline & $\begin{array}{l}\text { Min } \\
\text { score }\end{array}$ & 77.50 & 72.50 & 60.00 & 60.00 \\
\hline & $\begin{array}{l}\text { Max } \\
\text { score }\end{array}$ & 88.75 & 81.25 & 75.00 & 88.75 \\
\hline & $\begin{array}{c}N- \\
\text { gain }\end{array}$ & 0.62 & 0.48 & 0.37 & 0.49 \\
\hline \multirow[t]{2}{*}{ Normality } & $\begin{array}{l}\text { Sig (2- } \\
\text { tailed) }\end{array}$ & 0.995 & 1.000 & 0.306 & 0.604 \\
\hline & $\mathrm{H}_{o}$ & Accepted & Accepted & Accepted & Accepted \\
\hline \multirow{4}{*}{$\begin{array}{c}\text { Differential } \\
\text { Test }\end{array}$} & Mean & 27.08 & 21.67 & 17.08 & 21.92 \\
\hline & T-test & 18.57 & 12.29 & 7.084 & 17.074 \\
\hline & Sig & .000 & .000 & .000 & .000 \\
\hline & $\mathrm{H}_{o}$ & Rejected & Rejected & Rejected & Rejected \\
\hline
\end{tabular}

The researcher calculated the findings of pre-test and posttest score of the students with adequate motivation. The calculation was to find whether the WBL technique was effective in teaching English to Adequate motivation students. In general, the mean of pre-test to students with adequate motivation is slightly higher than the mean of pre-test to students with higher motivation. However, in post-test, the mean score shows that high motivation students get a higher mean score than the students with adequate motivation. The total mean post-test of high motivation group is 83.06. SD is 0.08 which indicates that the improvement is categorized as adequate. Moreover, the researcher calculated the findings of pre-test and post-test mean score of low motivation students who are treated before and after weblog-based learning. It shows that Ho is rejected represent how the cognitive skill of students with low motivation, has improved after the implementation of weblog-based learning technique. In other words, the implementation of weblog-based learning technique to students with low motivation in improving students' cognitive skill is effective. The aspect in which the Ho is accepted represents how the implementation of weblog-based learning technique to students with low motivation in improving students' cognitive skill is ineffective in the listening cognitive aspect.
Table 1 reported that the mean of all skills in pre-test was 55.29, while the mean of the post-test is 7.21. It means the students with the overall motivation increased after the treatment. This fact reveals that the students with high, adequate, and low motivation could improve their English ability through the technique. Weblogging in education has many advantages, such as to provide a real audience for students writing, to provide extra reading practise for students, to encourage students to participate, and to create an online portfolio. Therefore, the best way to exploit the students' motivation and guide them into successful language learner. It is in line with Sadikin and Saleh [22] that weblogging could exploit the students' motivation and guide them into successful language learner. They further assert that teacher should design and schedule the activities and foresee any technical problems before starting the English class session using the classroom blog, because it can only be used when it is connected to the internet. The findings are also consistent with the scholars that weblog provides an authentic and interesting tool to help students be more independent in learning. Thus, the use of weblog is a way to stimulate their English learning motivation [23-27]. It can be concluded that the implementation of weblog-based learning technique to students with high, adequate, and low motivation in improving students' English Language skills is effective.

Therefore, the best way to exploit the students' motivation and guide them into successful language learner.

\section{B. Teaching English Using Classroom-Based Learning Technique to Highly, Adequately, and Lowly Motivated Students}

Table 2 shows generally the mean of the students' pre-test before the implementation of classroom-based learning method to students with high motivation, the mean students' cognitive skill is 55.97 and the standard deviation is 7.68. Moreover, the improvement of students' language skills is also analysed to classify the improvement of each English language skills. The improvement of students' cognitive skill after the use of CBL to students with high and low motivation, in general, are scored 0.35 and 0.25. According to Hake's Category [21], the improvement is categorized as low. The rejected Ho aspect in the differential test means that the students' cognitive skill with all types of motivation could improve after the implementation of classroom-based learning. Meanwhile, the improvement of students' learning skills after the implementation of classroombased learning technique to students with adequate motivation in general is categorized as adequate. It can be concluded that the cognitive skill of students with adequate motivation has improved after the implementation of classroom-based learning. In the other hand, the implementation of classroombased learning is effective to improve the cognitive skill of students with adequate motivation. 
TABLE II. DESCRIPTION OF STUDENTS LANGUAGE SKILLS IN THE USE of CBL to STUdents WiTh High, AdEQUATE, AND LOW Motivation

\begin{tabular}{|c|c|c|c|c|c|}
\hline \multicolumn{6}{|c|}{ Teaching English Using Weblog-Based Learning } \\
\hline \multicolumn{2}{|c|}{ Description } & \multirow{2}{*}{$\begin{array}{c}\begin{array}{c}\text { High } \\
\text { Motivati } \\
\text { on }\end{array} \\
55.97\end{array}$} & \multirow{2}{*}{$\begin{array}{l}\begin{array}{c}\text { Adequate } \\
\text { Motivation }\end{array} \\
55.31\end{array}$} & \multirow{2}{*}{$\begin{array}{l}\begin{array}{c}\text { Low } \\
\text { Motivation }\end{array} \\
54.44\end{array}$} & \multirow{2}{*}{$\begin{array}{c}\begin{array}{c}\text { Overall } \\
\text { Motivation }\end{array} \\
55.25\end{array}$} \\
\hline \multirow[t]{4}{*}{ Pre-test } & Mean & & & & \\
\hline & $\begin{array}{c}\text { St. } \\
\text { deviation }\end{array}$ & 4.63 & 3.85 & 6.82 & 4.97 \\
\hline & $\begin{array}{c}\text { Min } \\
\text { score }\end{array}$ & 48.75 & 48.75 & 46.25 & 46.25 \\
\hline & $\begin{array}{l}\text { Max } \\
\text { score }\end{array}$ & 62.50 & 60.00 & 66.25 & 66.25 \\
\hline \multirow[t]{2}{*}{ Normality } & $\begin{array}{l}\text { Sig (2- } \\
\text { tailed) }\end{array}$ & 0.994 & 0.982 & 0.999 & 0.975 \\
\hline & $\mathrm{H}_{\boldsymbol{o}}$ & Accepted & Accepted & Accepted & Accepted \\
\hline \multirow[t]{5}{*}{ Post-test } & Mean & 70.83 & 71.67 & 65.56 & 69.58 \\
\hline & $\begin{array}{c}\text { St. } \\
\text { deviation }\end{array}$ & 11.15 & 8.23 & 7.58 & 9.12 \\
\hline & $\begin{array}{c}\text { Min } \\
\text { score }\end{array}$ & 47.50 & 57.50 & 52.50 & 47.50 \\
\hline & $\begin{array}{l}\text { Max } \\
\text { score }\end{array}$ & 85.00 & 82.50 & 73.75 & 85.00 \\
\hline & $N$-gain & 0.35 & 0.37 & 0.25 & 0.32 \\
\hline \multirow[t]{2}{*}{ Normality } & $\begin{array}{l}\text { Sig (2- } \\
\text { tailed) }\end{array}$ & 0.994 & 0.658 & 0.634 & 0.746 \\
\hline & $\mathrm{H}_{o}$ & Accepted & Accepted & Accepted & Accepted \\
\hline \multirow{4}{*}{$\begin{array}{c}\text { Differential } \\
\text { Test }\end{array}$} & Sig & 0.001 & 0.001 & 0.000 & 0.000 \\
\hline & T-test & 5.142 & 7.362 & 7.826 & 10.763 \\
\hline & Sig & .001 & 0.000 & 0.000 & 0.000 \\
\hline & $\mathrm{H}_{o}$ & Rejected & Rejected & Rejected & Rejected \\
\hline
\end{tabular}

It can be inferred that CBL technique does not only concern with the teacher being controlled of the learning environment, but it also emphasizes learning through various teaching techniques and providing challenging and stimulating activities. Language learning is not just learning the skills of listening, speaking, reading and writing but it consists of developing a communicative competence [28, pp. 2-3]. Based on the class observation, CBL technique had several of style through role-playing, group projects, volunteering, visual-aids, etc. Those activities were designed to address the students selfmotivation and enthusiasm in English language learning.

\section{The Effect of Interaction between Learning Techniques and Students' Level of Motivation in Improving Students' English Language Skills}

The interaction between learning techniques and student motivation in improving students' cognitive skills is determined by analysing the data from student motivation (high, adequate, and low) in learning (WBL and CBL) using two-way ANOVA. Before calculating the two-way ANOVA, the prerequisite tests were conducted, namely the normality and homogeneity of variance test.

TABLE III. RESUlTS OF TwO-WAY ANOVA OF STUDENTS' ENGLISH LANGUAGE SKILls N-GAIN BASED ON MOTIVATION CATEGORY

\begin{tabular}{|l|l|l|l|l|l|l|}
\hline \multicolumn{1}{|c|}{ Source } & $\begin{array}{c}\text { Squared } \\
\text { Sum }\end{array}$ & $\mathbf{d k}$ & $\begin{array}{l}\text { Squared } \\
\text { Average }\end{array}$ & $\mathbf{F}$ & Sig. & $\mathbf{H}_{\mathbf{0}}$ \\
\hline Learning & .401 & 1 & .401 & 23.781 & .000 & Rejected \\
\hline Motivation & .290 & 2 & .145 & 8.620 & .001 & Rejected \\
\hline $\begin{array}{l}\text { Learning* } \\
\text { Motivation }\end{array}$ & .074 & 2 & .037 & 2.206 & .120 & Accepted \\
\hline
\end{tabular}

Based on table 3, the data from the interaction of the students learning motivations and techniques to their English language ability shows that the $\mathrm{N}$-gain of interaction between the learning and motivation categories is higher than the probability value (sig.) or higher than $\alpha=0.05$. As result, there is no interaction between motivation categories and learning in improving students' English language skills. In other words, WBL and CBL for TEFL can be applied either for high motivation, adequate motivation, or low motivation. The effect of the interaction is graphically shown in figure 2. As a result, there is no interaction between motivation categories and learning in improving students' English language skills. Thus, this indicates that the implementation of weblog-based learning in the experimental group does not depend on the category of student motivation, or in other words, WBL and CBL for TEFL can be applied either for high motivation, adequate motivation, or low motivation.

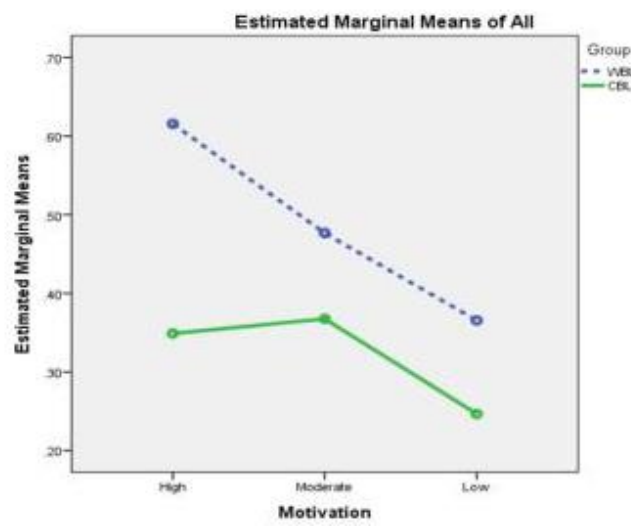

Fig. 2. Interaction between techniques and motivation category on students' English language skills.

The graph presents that the students with high motivation in WBL class show that they were able to reach the highest mean score by using WBL technique. It indicates that WBL for TEFL is effective in teaching English for highly motivated students. Meanwhile, the students with high motivation in CBL class shows that their mean scores are not as good as the students with adequate motivation. It is found that the students with adequate motivation could perform well through CBL technique. On that condition, the students with high motivation and low motivation need a special treatment since CBL technique could not accommodate their learning. In spite of the fact that WBL technique for students with low motivation shows the low mean score. It is found from the mean scores of lowly motivated students are not as good as students with adequate motivation. Above all, WBL for TEFL is deliberately more effective to improve English language skills to all motivation category.

This finding is in line with the constructivist theories which provide a framework in a digital age [29, p. 93]. He further explained that e-learning activities encourage learners to construct and engage new knowledge independently and solve 
problems [29,30]. It is strongly recommended that weblogbased learning be extended to help young learners develop their English language skills. It is strongly recommended that weblog-based learning be extended to help young learners develop their English language skills. It is an efficient way of improving the motivation of students to participate in important, contextual and, at the same time, challenging activities [22]. Similarly, webloging as one of online learning capture some advantages for learning $[6,31,32]$ for this reasons the result shows that the learners with high, adequate, and low motivation who learned English through WBL are better than CBL technique.

\section{CONCLUSION}

The evidence revealed that the average of $\mathrm{N}$-gain of both groups generally shows that students with WBL technique have higher average than the students with CBL technique. It can be found that that the sig (2-tailed) score of English skills were lower than 0.05 so that $\mathrm{H}_{0}$ is rejected. It means that there is a statistical difference in all motivation students in learning English through WBL and CBL techniques. As $\mathrm{H}_{\mathrm{o}}$ was accepted there was no statistical difference in learning English by the use of WBL and CBL. Both techniques were considered good to help the learners to enhance the students' learning. In fact, the average value of $\mathrm{N}$-gain in both groups indicated that students in WBL class got higher average on aspects compared to students in CBL class. Thus, it can be concluded that the experiment group is better in enhancing students' English language ability than the control group. Based on the interaction graph, the students with high motivation enabled to reach the high mean score by using WBL technique. Besides, the students with high motivation students in CBL class display that their means were not as good as the students with adequate motivation. As CBL technique could not accommodate the students with high and low motivation, they need to be given special treatment. Above all, WBL technique for TEFL is obviously more effective to improve English language skills to all motivation category.

\section{ACKNOWLEDGMENT}

My attention has recently been drawn to the headmaster of the school who gave me a chance to conduct the research and the School English teachers who helped to implement the techniques in class. Secondly, I would like to express my special thanks of gratitude to Esa Unggul University for providing me with all the facility that was required.

\section{REFERENCES}

[1] L. Čechová, E-Learning as a Support Tool for English Teaching to Young Learners. Doctoral dissertation, Czechia: Masarykova univerzita, Pedagogická fakulta, 2011.

[2] P.K. Gilbert and N. Dabbagh, "How to structure online discussions for meaningful discourse: A case study," British Journal of Educational Technology, vol. 36, no. (1), pp. 5-18, 2005.
[3] M. Yoshiko, I. Atsuko, and M. Yumi, "English Education in Japan From Kindergarten to University," in R. Reinelt, Ed. (2nd) FL Teaching Rudolf Reinelt Research Laboratory EU Matsuyama, 2009.

[4] J. Primavera, P.P. Wiederlight, and T.M. DiGiacomo, "Technology access for low-income preschoolers: Bridging the digital divide," The Annual Meeting of the American Psychological Association, vol. 6430, no. (203), pp. 1-26, 2001

[5] L. McManis and S. Gunnewig, "Finding the education in educational technology with early learners," YC Young Children, vol. 67, no. (3), pp. 14-24, 2012.

[6] T.F. Metaferia, "Using blogs to promote reflective language learning," Journal of Languages and Culture, vol. 3, no. (3), pp. 52-55, 2012.

[7] Z. Okan and H.U. Taraf, "The Use of Blogs in Second Language Teacher Education," Procedia - Social and Behavioral Sciences, vol. 83, pp. 282-289, 2013.

[8] J.F. Samson and B.A. Collins, "Preparing All Teachers to Meet the Needs of English Language Learners: Applying Research to Policy and Practice for Teacher Effectiveness," Center for American Progress, April 2012. [Online]. Retrieved from: http://eric.ed.gov/?id=ED535608

[9] T. Souriyavongsa, S. Rany, M.J.Z. Abidin, and L.L. Mei, "Factors Causes Students Low English Language Learning: A Case Study in the National University of Laos," International Journal of English Language Education, vol. 1, no. (1), pp. 179-192, 2013

[10] M.J. Guilloteaux and Z. Dörnyei, "Motivating Language Learners: A Classroom-Oriented Investigation of the Effects of Motivational Strategies on Student Motivation," TESOL Quarterly, vol. 42, pp. 5577, 2008.

[11] K. De Bot, W. Lowie, and M. Verspoor, Second language acquisition: An advanced resource book. London: Routledge, 2005a.

[12] K. De Bot, W. Lowie, and M. Verspoor, "Dynamic systems theory and applied linguistics: The ultimate "so what"?" International Journal of Applied Linguistics, vol. 15, no. (1), pp. 116-118, 2005b.

[13] F. Karahan, "Language attitudes of Turkish students towards the English language and its use in Turkish context," Journal of Arts and Sciences, vol. 7, pp. 73-87, 2007.

[14] Y. Tahaineh and H. Daana, "Jordanian Undergraduates â€TM Motivations and Attitudes towards Learning English in EFL Context," International Review of Social Sciences and Humanities, vol. 4, no. (2), pp. 159-180, 2013.

[15] N. Oroujlou and M. Vahedi, "Motivation, attitude and language learning," Procedia Social and Behavioral Sciences,vol. 29, pp. 994 1000, 2011

[16] C. Fen $\mathrm{Ng}$ and P.K. $\mathrm{Ng}$, "A Review of Intrinsic and Extrinsic Motivations of ESL learners," International Journal of Languages, Literature and Linguistics, vol. 1, no. (2), pp. 98-105 2015.

[17] J.R. Fraenkel and N.E. Wallen, How to Design and Evaluate Research in Education. New York. McGraw-Hill Companies, 2009

[18] P.R. Pintrich, "A Motivational Science Perspective on the Role of Student Motivation in Learning and Teaching Contexts," Journal of Educational Psychology, vol. 95, no. (4), pp. 667-686, 2003.

[19] P.R. Pintrich and E.V. de Groot, "Motivational and self-regulated learning components of classroom academic performance," Journal of Educational Psychology, vol. 82, no. (1), pp. 33-40, 1990.

[20] D.I. Newble, "The critical incident technique: a new approach to the assessment of clinical performance," Medical education, vol. 17, no. (6), pp. 401-403, 1983.

[21] R.R. Hake, “Analyszing Change/Gain Score Woodland Hills Dept.of Physics," Indiana University, 1999. [Online]. Retrieved from: http://physic.indiana.edu/sdi/analyzing Change-Gain: pdf. [Accessed on: May 28, 2013].

[22] I.S. Sadikin and M. Saleh, "Weblog-Based Learning in an EFL Young Learners' Context: Students' Perspective," Arab World English Journal (AWEJ), no. 3, pp. 58-78, 2016 
[23] S. Wheeler, P. Yeomans, and D. Wheeler, "The good, the bad and the wiki: Evaluating student-generated content for collaborative learning," British Journal of Educational Technology, vol. 36, no. (6), pp. 987-995, 2008.

[24] S.-H. Yang, "Using Blogs to Enhance Critical Reflection and Community of Practice," Educational Technology \& Society, vol. 12, no. (2), pp. 11-21, 2009.

[25] D. Zhang, "The Application of Blog in English Writing," Journal of Cambridge Studies, vol. 4, pp. 64-72, 2009.

[26] C. Trajtemberg and A. Yiakoumetti, "Weblogs: a tool for EFL interaction, expression, and self-evaluation," ELT journal, vol. 65, no. (4), pp. 437-445, 2011.

[27] Z. Zhang and R. Kenny, "Learning in an Online Distance Education Course: Experiences of Three International Students," International Review of Research in Open and Distance Learning, vol. 11, no. (1), pp. $17-36,2010$.
[28] B.M.L. Srivastava, S. Sitaram, R.K. Mehta, K.D. Mohan, P. Matani, S. Satpal, K. Bali, R. Srikanth, and N. Nayak, "Interspeech 2018 Low Resource Automatic Speech Recognition Challenge for Indian Languages," Proc. The 6th Intl. Workshop on Spoken Language Technologies for Under-Resourced Languages, pp. 11-14, 2018.

[29] A. Koohang, L. Riley, T. Smith, and J. Schreurs, "E-Learning and Constructivism: From Theory to Application E-Learning and ELearning Design What is Constructivism?" Elearning, vol. 5, pp. 91109,2009 ..

[30] A.F. Alzaghoul, "The Implication of the Learning Theories on Implementing e-learning Courses," The Research Bulletin of Jordan ACM, vol. 11, no. (11), pp. 27-30, 2012.

[31] S. Aydin, "The Use of Blogs in Learning English as a Foreign Language," Online Submission, vol. 4, no. (1), pp. 244-259, 2014.

[32] R.T.-H. Chen, "L2 Blogging: Who Thrives and Who Does Not?" Language Learning \& Technology, vol. 19, no. (192), pp. 177-196, 2015 